\title{
ELT teachers' epistemological beliefs and dominant teaching style: a mixed method research
}

\author{
Neda Soleimani
}

Correspondence:

Soleimani_neda92@yahoo.com

Shiraz University, Shiraz, Iran

\section{Springer Open}

\section{Introduction}

Epistemological beliefs (EBs hereafter) describing "individual representations (beliefs) about knowledge and knowing” (Mason \& Bromme, 2010, p. 1) guide teachers' behaviors and attitudes towards issues in classroom context (Araga o, 2011). EB describes teachers' beliefs about how knowledge is acquired. Teachers' EB is assumed to play a decisive part regarding how a teacher interprets knowledge, justifies the structure and source of information, and more generally how learning process unfolds (Gholami \& Husu, 2010).

Viewed as a significant component of teaching practicum in teacher education programs (Borg, 2006; Tang, 2007), teachers' initial conceptualization of teaching, pedagogical decisions and practices and whatever happening in a classroom are filtered through teachers' EB (Cheng, Chan, Tang, \& Cheng, 2009). Put it more specifically, EB has found its status in education as a variable affecting many learning and teaching

(c) The Author(s). 2020 Open Access This article is licensed under a Creative Commons Attribution 4.0 International License, which permits use, sharing, adaptation, distribution and reproduction in any medium or format, as long as you give appropriate credit to the original author(s) and the source, provide a link to the Creative Commons licence, and indicate if changes were made. The images or other third party material in this article are included in the article's Creative Commons licence, unless indicated otherwise in a credit line to the material. If material is not included in the article's Creative Commons licence and your intended use is not permitted by statutory regulation or exceeds the permitted use, you will need to obtain permission directly from the copyright holder. To view a copy of this licence, visit http://creativecommons.org/licenses/by/4.0/. 
related issues including learning motivation and strategies (Duell \& Schommer-Aikins, 2001), and instructional practices (Ng, Nicholas, \& Williams, 2010). As a hallmark of instructional practices, teaching styles might be justified through teachers' EB as well (Ng et al., 2010). Defined as a "predilection toward teaching behavior and the congruence between educators' teaching behavior and teaching beliefs" (Heimlich \& Norland, 1994, p. 34), teaching style is a manifestation of teachers' hidden assumptions and beliefs about what to do and what not to do in a classroom, tasks to be covered, materials to be selected and teacher-student interaction (Braten \& Stromso, 2005; Buehl, 2003). A line of demarcation must be drawn between teaching style and strategies. As teaching strategies are referred to a generalized lesson plan and teachers' behavior in terms of goals of instruction. Comparing to teaching styles which deal with theoretical mindsets that a teacher follows, strategies include practical items and performance a teacher does in classroom.

Cognizant of EB role in elucidating on teachers' practices (Roth \& Weinstock, 2013), a plethora of recent studies concentrated on how EB pinpoints the connection between beliefs and practices. Results of the earlier studies mainly highlighted the diversity of EB depending on teachers' background, subject matter and contextual variables (Kienhues, Bromme, \& Stahl, 2008). That said, studying the connection between EB in different disciplines (e.g. mathematics, psychology, etc.) and pedagogical aspects has been an interesting area of research (Hofer \& Pintrich, 2002). However, most of extant studies have been quantitative in nature and empirical studies focusing on the possible connection between teachers' EB and actual classroom practices and instructional preferences are missing (Sosu \& Gray, 2012).

Despite the amplitude of the studies into EB of teachers in different subject matters, English teachers' EB and the way through which EB could possibly find its pattern in and inform teaching styles seem to be far less investigated. Similar to other areas of teacher education, teaching styles might be rooted in how teachers perceive knowledge and define knowledge gaining resources. This under-investigated claim stimulated our study and motivated the researcher to do the current inquiry. Informed by Grasha's (2002) model of teaching style and Chan and Elliott's (2004) model of EB as the theoretical frameworks, this paper focused on EFL teachers' EB, teaching styles and the likelihood of connection between these two attributes.

To operationalize teaching style, the researcher used the definition proposed by Grasha (2002) whereby teaching style referred to a set of teachers' decisions regarding setting goals of teaching, managing classroom and learning tasks. This study used Chan and Elliott's (2004) model of EB to approach English teachers' beliefs about knowledge and knowledge construction. To operationalize this variable and measure teachers' EB, we used an EB questionnaire developed by the same authors (See the appendices for scales of measuring these variables).

\section{Theoretical framework Epistemological beliefs}

Bandura (1986) defined beliefs as a set of personal values filtering individuals' behavior and decisions as well as knowledge acquisition. Personal beliefs are believed to underpin what teachers do and how they behave in classroom (Olafson \& Schraw, 2006). 
Findings of the root of beliefs and the way that beliefs are created have been the topic of a plethora of studies into education.

Studying EBs has been recognized to be the first step toward triggering changes into teacher education programs and developing new insights into teaching profession (Lee \& Schallert, 2016). Analyzing elementary school teachers' beliefs about learning and teaching, Nespor (1987) suggested that teachers' EBs either implicitly or explicitly influence learners' beliefs about knowledge acquisition and curriculum development. A similar idea has also implied by Schraw and Olafson (2003) who labeled teachers' beliefs as important predictors of pedagogical outcomes. More specified questions, however, are related to the aspects of teaching behaviors affected by EBs. According to Donmoyer (2001) EBs are determinant elements defining how a teacher reacts in a classroom. Likewise, Tsai (2002) asserted daily routines and teachers' practices, deciding what to teach or the content of instruction mirror teachers' EBs about learners' role in knowledge construction and status of curriculum. Extending studies into EBs, Tsai and Kuo (2008) also proposed that classroom practices, classroom climate and management and instructional tasks are filtered by positivistic and or constructivist views. Similarly, Yang, Chang, and Hsu (2008) argued that teachers' EB was an important sign of teachers' values and how knowledge is shaped in learners. Extant studies showed that teachers holding more relativist and sophisticated EB tended to celebrate learners' latitude in constructing knowledge and classroom performance. Whereas teachers holding naïve epistemological beliefs tend to be more teacher-centered in their decisionmakings and practices in classroom (Chan, 2003).

Since the introduction of EB, many issues have been raised, added and modified by different scholars (Buehl, 2003; Gholami \& Husu, 2010; Schommer-Aikins, Duell, \& Hutter, 2005), yet the core meaning and main elements of epistemological beliefs are more or less the same (Hofer \& Pintrich, 1997). Perry (1970) is one of the pioneering scholars whose study into EB paved the way and provided illuminating insights for the later scholars. He approached EB from a developmental perspective to show how a person progresses through different stages to come up with EB. Perry's (1970) study showed that primary and less experienced learners begin with dualist beliefs whereby knowledge is absolute and teachers are responsible for imparting the knowledge bases to the learners. In next level, a person develops the idea of multiplism and views knowledge from more than one source, though the idea of a special truth to be discovered is the matter of debate. Relativism was the third dimension added to this model later on showing that knowledge acquisition sources are relative. The final and more sophisticated stage of this model is commitment within relativism involving personal judgment and evaluations incorporated with the commitment to the beliefs (Brownlee, Purdie, \& Boulton-Lewis, 2001; Hofer, 2001).

Schommer (1990) criticized Perry's classification of EB for being developmental and unidimensional and revisited the model. She proposed a belief system containing five dimensions: certainty of knowledge (ranging from absolute to tentative), structure of knowledge (from simple to complex), source of knowledge (given by an authority or created by personal reasoning), control of knowledge (fixed to changing and dynamic ability to learn something), and speed of knowledge acquisition (quick to gradual knowledge acquisition). Schommer used a quantitative approach to check the relationships between academic cognition and performance and developed a 63-item scale to 
examine the belief system. Schommer (1990) and Schommer, Crouse, and Rhodes (1992) conducted series of factor analyses and found four factors: simple knowledge, certainty of knowledge, fixed ability and quick learning. The first two dimensions were related to the beliefs about the nature of knowing and the other ones were concerned about learning beliefs (Schommer-Aikins, 2004).

As some factors did not emerge in validation studies, Chan and Elliott (2002, 2004) criticized Schumer's research method and rectified the EB model. In this model EB was diagrammed in connection with teachers' conceptions of teaching and learning (see Fig. 1). Four factors were extracted in Chan and Elliott (2004) study: Authority/Expert Knowledge, Certainty Knowledge, Learning Effort/Process and Innate/ Fixed Ability. According to this categorization, the first dimension shows the tendency to believe the presence of an authority to transfer the knowledge to the learners. The second one deals with the process through which knowledge is acquired: whether knowledge is something to be achieved by hard work and the third dimension deals with the point that whether knowledge is something fixed or changeable. Finally, the fourth category questions whether people perceive knowledge as an innate capacity or something to be constructed. In other words, from the perspective of innate/fixed ability believers' knowledge is something that could not be changed because the ability to gain and reshape knowledge is very limited.

\section{Teaching style}

Teachers' persistent patterns of behavior and actions representing minute variations are called teaching styles (Grasha, 2002). That said, teaching styles are personal predispositions and tendencies toward learning and pedagogy, which might be manifested differently in diverse contexts. To better conceptualize teaching style, Jarvis (2004) proposed the following definition:

A teacher's style is the totality of one's philosophy, beliefs, values, and behaviors, and it incorporates the full implementation of this philosophy; it consists of

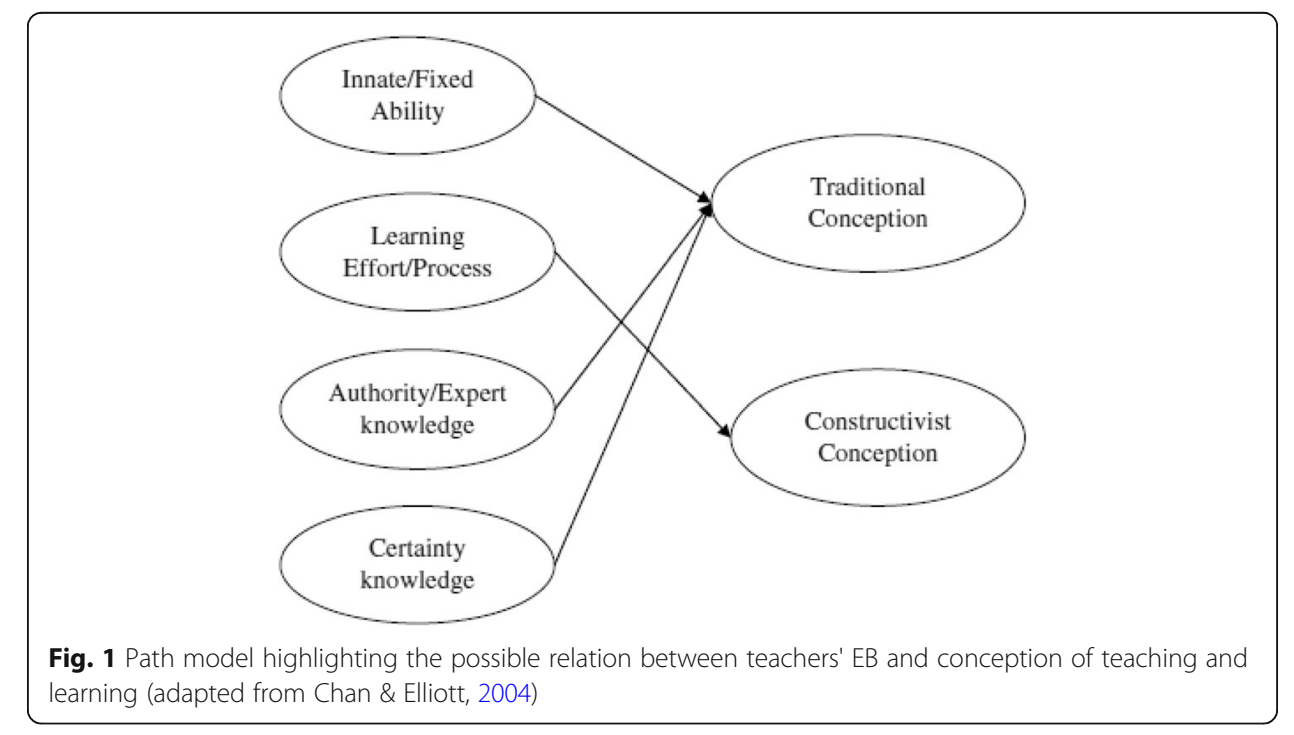


substantiation and support of beliefs about values and attitudes toward elements of the student learning and teacher learning exchange (p. 40).

As teaching styles are amalgamations of teachers' theoretical background and real pedagogical practices, multiple factors such as teachers' personality, cultural and social contexts, philosophy and theoretical background of teaching, subject matter, etc. might change teaching styles (Korthagen, 2004). As such, there is no good or bad style of teaching and a teacher might practice varying degrees of different styles of teaching, yet "the order of each style in the cluster reflects the perceived importance of that style in the blend" (Grasha, 2002, p. 153).

Depending on the mixture of these factors, teaching styles might be a reflection of teacher-centeredness or learner-centeredness. A teacher-centered style of teaching highlights teachers' control over classroom and assumes a passive role for the learners and teachers following teacher-centered styles act like a sage on the stage (Jarvis, 2004). Whereas, learner-centered style of teaching focuses on active role of learners in the classroom and acknowledge significant contribution of learners to pedagogy and teaching career (Grasha, 2002; Jarvis, 2004; Springer, Stanne, \& Donovan, 1999).

Language education studies have recommended diverse definitions and classifications for teaching styles. For instance, visual, auditory and kinesthetic teaching styles (Stensurd \& Stensurd, 1983), and a six-point model to teaching style by Henson and Borthwick (1984) in which task oriented, cooperative planner, child centered, participant-centered learning-centered and emotionally exciting styles are explained. Grasha (2002) formulated one of the most commonly referred frameworks for teaching styles. This integrated model categorizes teaching styles into five classes: expert, formal authority, personal model, facilitator, and delegator. A formal authority teacher considers himself as a school member who is recognized by his knowledge. He is mainly involved with giving feedbacks to students and establishing rules and expectations. The personal model teacher conceives himself as a model for students and students have to emulate his approaches. The next one is a facilitator teacher who follows teacher-student interaction, tries to guide students by asking questions and making suggestions, and encourages students to make informed decisions. The delegator teacher is distinguished as a resourceful person who is available when needed. This teacher attempts at training autonomous learners. Teachers might perform all styles of teaching to varying degrees, yet one style is more reflected in teaching career. As Grasha (2002) put it, "think of each one as representing a different color on an artist's palette. Thus the colors blend together in various ways with some combinations of styles or blends becoming dominant in teaching while others fall into the background" (p.140). In this study, we adopted Grasha's (2002) teaching style theory to focus on this variable as many studies have confirmed its validity (Dincol et al., 2011; LaBillois \& Lagacé-Séguin, 2007).

\section{Review of literature}

Teachers' belief is generally assumed a universal construct on which classroom effectiveness and practical aspects of teaching hinge upon (Pajares, 1992; Richardson, 1996). In this sense, EB is considered a context free notion to be examined in different disciplines and from multiple perspectives of education (Sosu \& Gray, 2012). Although 
epistemology has been touched upon from varying perspectives, researchers commonly focus on EB, "including beliefs about the definition of knowledge, how knowledge is constructed, how knowledge is evaluated, where knowledge resides, and how knowing occurs" (Hofer, 2001).

Owing to the solid theoretical frameworks proposed by Perry (1981), Schommer (1990) revised ideas and principles of EB (Chan \& Elliott, 2004; Schommer-Aikins, 2004), substantial studies have focused on the role of EB in teaching and learning process. Teachers' beliefs about knowledge acquisition affect teaching and teachers' behaviors in diverse contexts (Haberman, 1995, 1996). In a line of inquiry, Ravindran, Greene, and DeBacker (2005), utilized Schommer's (1990) model and examined 100 preservice teachers' EB. They found that teachers' different personal EB led to different teaching strategies. As an example, teachers who believed in authority as a source of knowledge followed a shallow processing strategy of teaching but those who thought that knowledge is acquired through reasoning adopted a deep processing strategy to teach.

In a number of studies conducted in Australia, (Brownlee et al. (2001) and Brownlee (2003) studied graduate teacher education students' EB and found that they believed in multidimensional belief system as put forward by Schommer (1990). Those who hold that truth is constructed through ample of evidence also considered a significant role for an expert to facilitate knowledge acquisition.

Children's learning, the process of choosing stories and teaching approaches are also filtered through teachers' EB (Olafson \& Schraw, 2006). Teachers holding sophisticated EB inclined to affirm learner-centered approaches to teaching and helped learners construct their knowledge. On the contrary, teachers who believed in naive belief system tended to practice transmission and teacher-centered styles of teaching (Sinatra \& Kardash, 2004; Yadav \& Koehler, 2007). Teachers holding sophisticated beliefs also have been found to use integrated strategies of teaching which create chances for group discussion and involve learners in problem solving tasks (Hashweh, 1996).

Pre-service teachers' conceptions about teaching and learning could also be under the influence of EB. Earlier studies classified teachers into two categories: those who believe in traditional teaching and learning and constructivist learning and teaching (Brooks \& Brooks, 1999; Cheng et al., 2009; Eren, 2010). Teaching didactically, traditional teachers presume that they are the source of information to be passed down to the learners. Chan (2003) asserted that pre-service teachers who believed in constructivist conceptions tend to consider knowledge as a tentative phenomenon and those with traditional conception think that knowledge is certain and fixed. Chan and Elliott (2004) in a complementary study found that pre-service teachers innate/fixed beliefs, authority/expert and certainty knowledge beliefs were positively connected to traditional conceptions and practices of teaching, yet learning effort beliefs were positively related to constructivist teaching practices. In congruence with findings of this study, Cheng et al. (2009) found that student teachers who believed in sophisticated EB performed learner-centered and constructivist teaching practices and acknowledged the role of active participation and critical thinking in learning. Using statistical analyses, Sosu and Gray (2012) tracked the epistemic beliefs in teachers' behaviors and instructional preferences. Their regression analyses showed that teachers' EB significantly predicted their instructional preferences and the teachers who believed in learning effort 
as the main channel of knowledge acquisition tended to practice student-centered instructional tasks and adapted teaching to the students' needs.

In addition to being context free, teachers' EB has been recognized to be highly domain specific (Buehl \& Alexander, 2005; Hofer, 2001; Muis, Bendixen, \& Haerle, 2006) and differ across individuals and subject matters (Hofer, 2000; Kaartinen-Koutaniemi \& Lindblom-Ylänne, 2008). In a categorization by Schommer-Aikins, Duell, and Barker (2003) teachers and researchers of hard academic disciplines (e.g. physics, engineering and chemistry) view knowledge as having fixed patterns to be discovered. However, in soft science (e.g. education, language and literature), a lack of structured paradigm is recognized and knowledge acquisition manners fuel academic and scholarly debates. This argument implies that depending on the subject matter teachers organize instructional activities and respond to pedagogical needs differently (Kuhn \& Weinstock, 2002).

Similar to teachers of other disciplines, much of EFL teachers' EB are embodied in their classroom discourse and behaviors. EFL pre-service teachers' EB determines their cognitive and metacognitive strategies (Cotterall, 1999; Horwitz, 1999). EFL contexts are distinguished for unique cultural background that might ignite specific EB (Clarebout, Elen, Luyten, \& Bamps, 2001). Flores (2001) and Arkoudis (2003) also argued that language teachers' EB are formulated in particular socio-economic contexts leading to expectedly different teaching behaviors. In Saudi, Abd Alsmaie and Ammar (2011) investigated the relationships between EFL pre-service teachers' EB and their learning strategies, teaching practices and foreign language classroom anxiety. One hundred fourteen pre-service EFL teachers participated in that quantitative study and filled EFL EB questionnaire, EFL learning strategies questionnaire and EFL teaching practices questionnaire. Results of their study showed that Saudi Arabian EFL pre-service teachers showed tendency towards traditional, memorization and rehearsal practices of teaching rather than higher order and elaboration tasks of teaching. In the context of Iran, Ketabi, Zabihi, and Ghadiri (2012) studied Pre-service English teachers' epistemological beliefs and their conceptions of teaching. To collect data, they handed EB scale of teaching and learning conception questionnaire to 92 Iranian pre-service EFL teachers. They found that EFL pre-service teachers endorsed innate/fixed ability and therefore traditional conception of teaching. Additionally, significant correlations were observed between teaching conceptions and teachers' EB.

Janfeshan (2017) studied Iranian EFL teachers' beliefs about teaching grammar. In a mixed research, the researcher found that teachers emphasized teaching grammar as an important aspect of communication. Teachers also asserted that examination-oriented culture of education in Iran and the necessity of preparing learners for universityentrance examination force teachers to spend more time on grammar in language teaching.

In a more recent study, Mardali, Siyyari, and Lu (2019) found that teacher' beliefs about teaching vocabulary in which EFL teachers believed that their major role is explaining about vocabularies and use direct method of teaching.

In bringing together, the discussion started in review of literature, teachers' EB are acknowledged as essential elements introducing permanent changes in instructional plans and practices (Chan, 2003).

Teachers' beliefs and its anchors in teacher's practices have been a hot topic for most of the studies in recent decades (Borg, 2006). Most prominent assertions of these 
studies are manifestation of EB as a system of core and peripheral beliefs, the impact of contextual variable mediating teachers' $\mathrm{EB}$ and the tension that might appear as the result of conflict between beliefs and practices (Borg, 2006). Yet, research giving credence to these claims has its own limitations as most of empirical evidence for the nature of beliefs comes from studies about pre-service teachers and graduate teachers teaching hard science and EB in language education, an ill-defined soft domain of knowledge, have been the topic of scant attention. Furthermore, EB has been claimed to be a contextually dependent issue, which restricts the generalizability of earlier studies and brings up the necessity of doing research to enlighten the nature of English language teachers' EB system. To obviate this necessity, in this study we deal with predominantly espoused types of EB, how system of EB finds its path into the language teachers' teaching practices and inform dominant teaching styles in private language learning centers. In particular, this research sought to answer the following questions:

1. What do predominantly EFL teachers believe about the resource of knowledge and knowledge acquisition?

2. What teaching styles do EFL teachers predominantly follow?

3. In what sense are EFL teachers' teaching styles informed by their beliefs about knowledge acquisition resources?

\section{Methodology}

\section{Context and participants}

To answer the research questions, both quantitative and qualitative methods of research were used to compensate for the weaknesses of either of methods and gain a more reliable and valid picture of issues being examined (Riazi \& Candlin, 2014). A mixture of data gathered through questionnaire and semi-structured interview enables the researchers to delve into the participants' mind patterns, thoughts and insights. As for the quantitative phase of this study, through convenient sampling, two cities (Yasuj and Gachsaran, located in southwest of Iran) were chosen. According to Ary, Jacobs, Sorensen, and Razavieh (2010), cluster sampling is a type of probability sampling in which units of people who are naturally together and share common features are selected. Relying on a list of the Provincial Office of Education, 70 institutes exist in Yasuj and Gachsaran from which 35 clusters were randomly selected. The selected clusters in this study comprised 200 EFL teachers who filled out the questionnaires. $45 \%$ of the participants were female and $55 \%$ of them were male. About $65 \%$ of the samples held B.A. in teaching English as a foreign language and 35\% of the samples obtained M.A. in the same major. All of the participants were originally from Iran and their native language was Farsi. Twenty participants of this sample were selected through systematic random sampling for the follow-up semi-structured interview sessions.

\section{Instruments}

The teaching style inventory (TSI) developed by Grasha (2002) was administered to survey the participants' teaching styles (see the appendix). TSI is a forty-item questionnaire based on a five-point Likert scale which is rated from 1 (strongly disagree) to 5 (strongly agree) and categorized teaching styles into five main classes: (a) expert, (b) formal authority, (c) personal model, (d) facilitator, and (e) delegator. Each subscale has 
eight items addressing teachers' teaching options and preferences. The overall Cronbach alpha estimated for five subscales of TSI was .75.

Epistemological belief scale (EBS) developed by Chan and Elliott (2004) was used to collect data about EFL teachers' epistemological beliefs (see the appendix). In comparison to the previous scales of $\mathrm{EB}$, this questionnaire is more user-friendly and contains less number of items, yet the scale is comprehensive and valid. EBS includes 30 items based on a five-point Likert scale whereby " 1 " means "strongly disagree" and " 5 " means "strongly agree". This belief scale aimed at measuring innate/fixed ability (13 items), learning effort/ process (6 items), authority/expert knowledge (6 items), and certainty knowledge (5 items). Innate/fixed ability assesses teachers' beliefs about whether people's capabilities are exposed to change. Learning effort/process deals with teachers' beliefs about work and hard efforts to learn something. Authority/expert measures teachers' beliefs in regard with the way that individuals learn something and if knowledge is obtainable from authorities or personal judgment and justifications. Certainty knowledge evaluates teachers' beliefs concerning the consistency of knowledge. The Cronbach alpha for EBS was .82. The questionnaires were handed to the EFL teachers in person and to ensure their full cooperation, a small gift was offered to each of them.

Capturing belief system is generally difficult as most of teachers are not aware of what they believe (Kagan, 1992). For this reason, describing beliefs might be more reliable when quantitative methods are coupled with qualitative research methods whereby richer insights are promised (McCrum, 2013). That said, we conducted 20-min semi-structured interviews in Farsi to approach an enhanced understanding of EFL teachers' EB, and how EB inform teaching styles (the interview questions are included in appendix).

\section{Data collection and analysis}

We informed the participants about the purpose of the study and explained the meaning of EB and teaching style to the participants before distributing the scales. Then semistructured interviews were conducted. To do so, the researcher asked for participants' permission to record their voice (see Appendix for the interview questions). Qualitative data collection was pursued until data saturation point that was the 15th interview. Following that, using code and theme analyses (Charmaz, 2006), we transcribed the taperecorded interviews and extracted the main themes and codes. After data collection, we used systematic qualitative analyses approach (Strauss \& Corbin, 1998) to transcribe, break the codes and extract the main themes and subthemes of the data. To ensure the reliability and validity of the research, we made our determined effort to focus on "indigenous concepts" (Patton, 1990) and removed them from data analyses. To this end, we asked two coders to check for redundancy and transparency of the major themes extracted from the interviews and field notes. Statistical Package of Social Science (SPSS) was used to perform quantitative data analyses. Correlational and regression analyses were implemented to check the results of quantitative phase of the study.

\section{Results}

\section{Results of quantitative analysis}

Descriptive statistics were used to find the prevalent epistemological beliefs that EFL teachers mainly hold and discover EFL teachers' dominant teaching style. Results of the 
study showed that EFL teachers' dominant teaching styles were facilitator style (mean = $35, \mathrm{SD}=4.5$ ), expert style (Mean $=33.27, \mathrm{SD}=3.7$ ), formal authority (mean $=32.24$, $\mathrm{SD}=3.5)$, delegator $($ mean $=31.44, \mathrm{SD}=3.4)$, and personal model $($ mean $=29.20, \mathrm{SD}=$ 3.2). Descriptive statistics of EFL teachers' epistemological beliefs were represented in the following table. As seen in this table, EFL teachers' predominant epistemological belief is learning process (see the following Tables 1 and 2).

To examine the relationships among EFL teachers' epistemological beliefs and dominant teaching style, Pearson correlational analyses were conducted. Results of these analyses illustrated that there existed significant relationships between these variables (Table 3).

According to this table, significant positive relationship at 0.01 existed between EFL teachers' dominant teaching style (facilitator) and epistemological beliefs (learning process $)(\mathrm{r}=.685, p<0.01)$ meaning that the more EFL teachers believe that knowledge is acquired through effort, the more facilitating role they play in their teaching styles.

To examine whether EFL teachers' EB could determine their dominant teaching style, linear regression analysis was carried out. The independent or predictor variable was EFL teachers' EB and dependent variable was EFL teachers' dominant teaching style. Enter method was used to do regression analysis. The following table shows the model summary (Table 4).

According to this table, $\mathrm{R}$-value is the correlation between entered variables and $\mathrm{R}$ square is the degree of variance that independent variable can account for dependent variable. $R$ square in this table shows that $46 \%$ of the variance in dependent variable could be accounted for by independent variable (EFL teachers' epistemological belief). ANOVA table demonstrates the significance of regression model (Table 5).

According to ANOVA, F (1,103) equals18.089 and sig ( $p$ value) is $.000, p<0.05$ which shows that the independent variable could significantly explain the amount of variance in the dependent variable. The following table shows multiple regression equations coefficients. Based on Beta value, EFL teachers' epistemological belief (learning process) contributes to $65 \%$ of facilitator style of teaching at the level of 0.05 and it is considered as a significant predictor of variable $(p<0.05)$ (Table 6$)$.

\section{Results of qualitative analysis}

Semi-structured corroborated the quantitative results showing the traces of teachers' EB in teaching style. Participants of this study were required to elaborate on the ways that their beliefs about sources of knowledge would inform their dominant teaching style. They believed that their material selection, relationship with students, and overall teaching styles are mirrors reflecting EB. Results of semi-structured interviews showed

Table 1 Descriptive Statistics of Teaching Style

\begin{tabular}{llll}
\hline Teaching style & Mean & Standard deviation & N \\
\hline Facilitator & 35.00 & 4.5 & 200 \\
Expert & 33.27 & 3.7 & 200 \\
Formal authority & 30.24 & 3.5 & 200 \\
Delegator & 27.44 & 3.4 & 200 \\
Personal model & 25.20 & 3.2 & 200 \\
\hline
\end{tabular}


Table 2 Descriptive statistics of EBS

\begin{tabular}{llll}
\hline Epistemological beliefs & Mean & SD & N \\
\hline Learning process & 41.42 & 2.8 & 200 \\
Authority & 32.87 & 3.7 & 200 \\
Innate ability & 29.89 & 1.25 & 200 \\
Certainty & 21.23 & .8 & 200 \\
\hline
\end{tabular}

that the ability to learn is not an innate but a changeable asset and most of learners can enhance and improve their capacities to learn a language. The teachers believed that language knowledge is acquired through persistent practice and diligence. This idea is well reflected in the following interview excerpt: "language learning in Iran is highly dependent on the amount of extracurricular activities and out-of-class efforts a person might put into the task. So, I believe that students have very limited chance of learning the language in the class and if they really want to master the skills, they have to take every learning chance everywhere". They asserted that knowledge acquisition resources are not restricted to books and experts of the field. Therefore, they try to use multiple media to teach and help learners build knowledge base. In support of this point, one of the teachers commented, "Language knowledge acquisition is possible through effort, though some learners are genetically endowed with a great talent to learn a language and this, undoubtedly, helps them outperform and get greater achievements. Therefore, when I teach, I focus on my students' abilities and encourage them to do their best".

Appreciating the learners' active participation in constructing the knowledge base, the participants of this study emphasized their role in providing chances for learners to have their shares. One of the teachers explicated, "I think a teacher is supposed to be flexible when he/she teaches. For example, I try to be friendly and have a warm connection with my learners. This way I can see what they need and how they learn and help them with their learning challenges". In a similar vein, another teacher remarked "the ability to learn needs to be reinforced. I am here to give them food of thought and help my learners in their learning process. In fact, learning process takes time and perseverance and knowledge is not an innate asset". As for source of knowledge, the teachers believed that multiple sources might come at play when a person acquires knowledge. Moving from the very simple and basic bases of knowledge to sophisticated and more comprehensive body of knowledge is possible when more than one source is exploited. Participants of this study confirmed the role of textbooks as a primary source of knowledge, yet they claimed that building a sound body of knowledge requires using more resources and media:

"TV shows, short stories, games and audio podcasts are just some examples of available sources that can assist learners and help them construct sophisticated

Table 3 Correlational Analyses between Epistemological Belief and Teaching Style

\begin{tabular}{llllll}
\hline Variables & 1 & 2 & SD & N & Sig \\
\hline 1.learning process & & $.685^{* *}$ & 2.8 & 200 & .002 \\
2. facilitator & $.685^{* *}$ & & 4.5 & 200 & .002 \\
\hline
\end{tabular}

Correlation is significant $\left(^{* *}\right)$ at $p<0.01$ (2-tailed) 
Table 4 Model Summary

\begin{tabular}{ccccc}
\hline Model & R & R square & Adjusted R Square & Std. Error of the Estimate \\
\hline 1 & .685 & .469 & 466 & 4.92423 \\
\hline
\end{tabular}

knowledge base. It is like learning alphabets, first starting with the books and content of the books and then reading some other magazines and journals. So these secondary sources are very helpful in expanding vocabulary and linguistic information".

Giving credence to the role of critical thinking and enabling the learners to produce novel structures was another theme extracted from the interviews. Highlighting the status of uncertainty and doubt as the first step of learning, another teacher stated that, "We are here to share some basic structures and vocabulary and help learners create the language knowledge but they must work for their own understanding and learn to justify and argue". To offer such an experience, teachers of this study asserted that they develop group discussion and peer activities to assist the learners in their language productions.

\section{Discussion and conclusion}

This study followed threefold research objectives: EFL teachers' dominant teaching styles and EB, the connection between these two variables and how EFL teachers' dominant teaching style might be informed by EB. This study showed that EFL teachers predominantly practice facilitator style of teaching. Both quantitative and qualitative results indicated that EFL teachers inclined to student-centered and constructive practices of teaching.

To interpret the findings of this study it must be noted that the data were collected from private language learning centers in which communications and improving speaking and listening skills are largely emphasized. In such a context, EFL teachers mainly believed learning is malleable and learning effort is the major source of knowledge acquisition. Learners were believed to have shared responsibility in teaching and actively contribute to the pedagogy. In the face of sticking to learning process as the predominant source of knowledge acquisition, ELT teachers seemed to choose facilitator role to direct this process. A Facilitator teacher makes effort to give positive feedbacks and increase motivation of learners (Grasha, 2002). This finding reflects the idea of knowledge transformation rather than transmission propagated by post method proponents. Post method era in language education features and celebrates learners' voice and sensitizing practitioners to learners' needs and their cultural backgrounds. New streams of teaching practices were much earlier quoted in Kumaravadivelu' (1994) post method condition emphasizing a reconsideration of traditional conception of teaching. In post method era, students are not considered as mere consumer or passive recipient of the

Table 5 ANOVA (for significance of regression model)

\begin{tabular}{llllcll}
\hline & & Sum of squares & df & Mean square & $F$ & Sig. \\
\hline Model & Regression & 4233.650 & 1 & 4233.650 & 174.598 & $.000^{a}$ \\
1 & Residual & 4801.105 & 198 & 24.248 & & \\
& Total & 9034.755 & 199 & & & \\
\hline
\end{tabular}


Table 6 Coefficients of predictor and dependent variables

\begin{tabular}{|c|c|c|c|c|c|c|}
\hline & & Unstan & coefficient & Standardized coefficients & $\mathrm{t}$ & Sig. \\
\hline & & $\bar{B}$ & Std. error & Beta & & \\
\hline Model & constant & 20.184 & 2.155 & & 9.366 & .000 \\
\hline 1 & & .548 & .041 & .651 & 13.214 & .000 \\
\hline
\end{tabular}

knowledge but they must be actively engaged in the process of learning and knowledge construction. In one of his widely cited articles, Kumaravadivelu (1994) sets an agenda for English language teachers mapping some macro strategies whereby maximizing learning opportunities, promoting learner autonomy, contextualizing linguistic input and facilitating negotiated interaction were specifically highlighted. Findings of this study suggested that the teachers started reconsideration of teaching concept and made primary steps to move from didactic approaches to teaching to constructivist conception and practicing student-centered teaching styles and used learner-centered tasks such as group discussion, role-play activities and pair talks demanding the learners' active involvement with learning are manifestation of this set of EB. Results of this study stressed the teachers' insistence on improving critical thinking abilities and the capability of argumentation, interactive real world communication, and reasoning among learners which resonate teachers' approach to learner-centered pedagogy. This finding verifies Iranmehr and Davari (2017) study emphasizing teachers' attempts in private language learning centers to enhance the learners' communicative skills. In addition, this piece of finding is in congruence with Moodie (2016) that indicated the curricular reforms and new orientations of teaching preached in second language education stressing the role of communicative language, establishing a warm teacher-student interaction and EFL teachers' adaptive pedagogies. On the contrary, Wong and Chai's (2010) study showed that teachers embracing traditional EB and sticking to the role of authority knowledge in teaching would view teaching as full transmission of knowledge and carry out teacher-centered styles of teaching.

Unlike this study, Janfeshan (2017) and Mardali et al. (2019) found that Iranian EFL teachers stressed the role of teachers in classroom rather than highlighting learners' voice. Their study indicated consistency between beliefs, practices, and using teachercentered pedagogy. They argued that exam culture and traditional method of teaching are two main reasons for over-emphasized status of teachers in education in Iran. Differences between findings of this study and earlier ones, might be justified through teachers' experiences and institutional conventions which might affect teachers' beliefs and understanding.

Regarding the connection between ELT teachers' dominant EB and teaching style, correlational and regression analyses indicated that these two attributes were significantly related to each other and EB significantly accounted for the changes in teaching styles. This piece of finding supports Chan and Elliott's (2004) study showing positive correlation between teaching concept and practices. They found that teachers holding traditional EB practiced traditional and teacher-centered instruction whereas those adhering to learning process as the foremost source of knowledge acquisition implemented constructivist-teaching practices. This idea was also evident in Cheng et al. (2009) investigation suggesting that teachers' sophisticated EB resulted in designing activities that motivate critical thinking and learners' engagement. Moreover, Sosu and 
Gray (2012) examining the connection between teachers' EB and teaching preferences found that EB significantly predicted teachers' instructional preferences. They also found that teachers' instructional practices and EB change from naïve to sophisticated as they face challenges in their profession.

Overall, although most of the studies reviewed earlier focused on pre-service teachers and non-ELT teachers, our findings presented supportive pieces of evidence for the influence of epistemological beliefs on teaching practices and styles. Cultural background, curricular and contextual variable might introduce some changes in teachers' EB (Windschitl, 2002). On the same page, Moodie (2016) found that that ELT teachers participating in this study have initiated to reform their beliefs with respect to sources of knowledge acquisition and made big leaps to upgrade their teaching career and update their teaching to meet the standards of the latest curricular changes in language education. This might be of much interest when changes in teacher education are tracked and challenges and mismatches between teachers' beliefs and practices pose obstacles (Lim \& Chai, 2008).

As an instance of studies into language teacher education, this study might carry some implications. Tracing ELT teachers' EB and focusing on its connection with different aspects of teaching might justify the reasons behind teachers' decisions and actions. Doing so might provide insights for teacher educators to reflect upon instructional choices made by teachers (Chan \& Elliott, 2004; Hofer, 2004). Armed with such an understanding, teacher education programs might be able to capitalize the efficient beliefs and practices. Further, as the status of reflectivity is a consistently pronounced element in effective teaching, findings of this study might accentuate the significance of contemplation of what teachers do and how it is connected with higher levels of thinking and belief system. The development, potential strengths and drawbacks of instructional practices, and efficacy of curricular revolutions might be accentuated through studies into teachers' EB and teaching related factors. As reviewed in the related studies, very few studies have focused on ELT teachers' EB and its connection with teaching practices. Thus, findings of this study portraying only limited aspect of ELT teachers' EB and teaching style may contribute to filling the gap in the current literature of ELT teacher education studies. As asserted earlier, drawing a clear-cut border between different types of EB and teaching style might not be an easy task due to the flexibility and variable nature of beliefs and style. However, this study did not deal with this dynamic system and a static picture of the research problems. Future studies may address how teachers' EB and teaching styles might transform as they grow professionally and gain more experiences and redefine their values. This type of research might be best implemented through longitudinal qualitative research designs and methods of data collection (e.g. self-reflective journals and self-reported practices).

This study provided a static and small scale picture of language teachers in south west of Iran which means the generalizability of findings must be performed cautiously. To present a deeper understanding of the issues, we suggest that future studies use a qualitative instrument (field note, observation or journal writing) to record more detailed information on how ELT teachers teach and gain a moment-by-moment report of teaching practices. While developments of teachers' EB and teaching styles changes as a result of professional development would yield illuminating insights into teacher education programs, this study did not deal with the question as to how teacher training might shape and change teachers' EB and teaching styles. 
This study dealt with a general overview of EFL teachers' EB and their teaching style and, due to feasibility issues, failed to approach teachers' EB about teaching different language skills (e.g. speaking, grammar, vocabulary, etc.). The question as to how ELT teachers' EB regarding different sub-components of language affect their teaching style could be a worthy line of further research. To do so, items of EB scale should be adapted to pinpoint teachers' beliefs about sources and quality of gaining grammatical, lexical and vocabulary knowledge to name a few.

Moreover, teachers' EB, thinking and cognition are shaped within and through the cultural background (Hofer, 2004), and new teaching and learning experiences. In this study we only examined ELT teachers' EB and teaching style regardless of their cultural variables. Therefore, the question as to what cultural background are ELT teachers exposed to and how these cultural features interplay between the beliefs and performance of ELT teachers are still open to research. Finally, as Chai, Teo, and Lee (2009) posited the role of school in developing the EB system and teaching and learning decisions, our study extends the questions surrounding the role of teacher education in providing a well-defined framework for tracing ELT teachers' EB development from naive to sophisticated and grasping the factors affecting this path.

\section{Appendix}

\section{Epistemological Beliefs (Chan \& Elliott, 2004)}

1 There isn't much you can do to make yourself smarter as your ability is fixed at birth.

2 Our abilities to learn are fixed at birth.

3 One's innate ability limits what one can do.

4. Some people are born good learners; others are just stuck with limited abilities.

5 Some children are born incapable of learning well in certain subjects.

6 The ability to learn is innate/inborn.

7 Students who begin school with "average" ability remain 'average' throughout school.

8 The really smart students don't have to work hard to do well in school.

9 If people can't understand something right away, they should keep on trying.

10 Knowing how to learn is more important than the acquired facts.

11 One learns little if one does not work hard.

12 Understanding course materials and thinking process are more important than acquiring knowledge/facts.

13 Everyone needs to learn how to learn.

14. People will learn better if they focus more on the process of understanding rather than the facts to be acquired

15 Learning something really well takes a long time or much effort.

16 How much you get from your learning depends mostly on your effort.

17 Getting ahead takes a lot of work.

18 If one tries hard enough, then one will understand the course material.

19 Wisdom is not knowing the answers, but knowing how to find the answers.

20 Sometimes I don't believe the facts in textbooks written by authorities.

21 Even advice from experts should often be questioned. 
22 I often wonder how much experts really know.

23 I am very aware that teachers/lecturers know a lot more than I do and so I agree with what they say is important is important rather than rely on my own judgment.

24 I still believe in what the experts say even though it differs from what I know.

25 I have no doubts in whatever the experts say.

26 Scientists will ultimately get to the truth if they keep searching for it.

27 If scientists try hard enough, they can find the truth to almost anything.

28 Anyone can figure out difficult concepts if one works hard enough.

29 I believe there should exist a teaching method applicable to all learning situations.

30 Scientific knowledge is certain and does not change.

\section{Teaching Style Inventory (TSI)}

Respond to each of the items below in terms of how you teach General English. Try to answer as honestly and as objectively as you can. Resist the temptation to respond as you believe you should or ought to think or behave, or in terms of what you believe is the expected or proper thing to do.

items

$\begin{array}{lllll}1 & 2 & 3 & 4 & 5\end{array}$

1. Facts, concepts, and principles are the most important things that studentsShould acquire.

2. I set high standards for students in this class.

3. What I say and do models appropriate ways for students to think about issues in the content.

4. My teaching goals and methods address a variety of student learning styles.

5. Students typically work on course projects alone with little supervision form me.

6. Sharing my knowledge and expertise with students is very important to me.

7. I give students negative feedback when their performance is unsatisfactory.

8. Students are encouraged to emulate the example I provide.

9. I spend time consulting with students on how to improve their work on Individual and/or group projects.

10. Activities in this class encourage students to develop their own ideas about Content issues.

11. What I have to say about a topic is important for students to acquire a broader Perspective on the issues in that area.

12. Students would describe my standards and expectations as somewhat strict and rigid.

13. I typically show students how and what to do in order to master course content.

14. Small group discussions are employed to help students develop their ability to think critically.

15. Students design one of more self-directed learning experiences.

16. I want students to leave this course well prepared for further work in this area.

17. It is my responsibility to define what students must learn and how they Should learn it.

18. Examples from my personal experiences often are used to illustrate points about the material.

19. I guide students' work on course projects by asking questions, exploring options, and suggesting alternative ways to do things.

20. Developing the ability of students to think and work independently is an important goal.

21. Lecturing is a significant part of how I teach each of the class sessions.

22. I provide very clear guidelines for how I want tasks completed in this course.

23. I often show students how they can use various principles and concepts.

24. Course activities encourage students to take initiative and responsibility for their learning.

25. Students take responsibility for teaching part of the class sessions. 
Teaching Style Inventory (TSI) (Continued)

\begin{tabular}{|c|c|}
\hline items & 12345 \\
\hline \multicolumn{2}{|l|}{ 26. My expertise is typically used to resolve disagreements about content issues. } \\
\hline \multicolumn{2}{|l|}{ 27. This course has very specific goals and objectives that I want to accomplish. } \\
\hline \multicolumn{2}{|l|}{ 28. Students receive frequent verbal and/or written comments on their performance. } \\
\hline \multicolumn{2}{|l|}{ 29. I solicit student advice about how and what to teach in this course. } \\
\hline \multicolumn{2}{|l|}{ 30. Students set their own pace for completing independent and/or group projects. } \\
\hline \multicolumn{2}{|l|}{$\begin{array}{l}\text { 31. Students might describe me as a "storehouse of knowledge" who dispenses thefacts, } \\
\text { principles, and concepts they need. }\end{array}$} \\
\hline \multicolumn{2}{|l|}{ 32. My expectations for what I want students to do in this class are clearly defined in the syllabus. } \\
\hline \multicolumn{2}{|l|}{ 33. Eventually, many students begin to think like me about course content. } \\
\hline \multicolumn{2}{|l|}{ 34. Students can make choices among activities in order to complete course requirements. } \\
\hline \multicolumn{2}{|l|}{$\begin{array}{l}\text { 35. My approach to teaching is similar to a manager of a work group who delegates tasks and } \\
\text { responsibilities to subordinates. }\end{array}$} \\
\hline \multicolumn{2}{|l|}{ 36. There is more material in this course than I have time available to cover it } \\
\hline \multicolumn{2}{|l|}{ 37. My standards and expectations help students develop the discipline they need to learn } \\
\hline \multicolumn{2}{|l|}{$\begin{array}{l}\text { 38. Students might describe me as a "coach" who works closely with someone to correct } \\
\text { problems in how they think and behave. }\end{array}$} \\
\hline 39. I give students a lot of personal support and encouragement to do well in this course. & \\
\hline me the role of a resource person who is available to students whenev & \\
\hline
\end{tabular}

\section{Interview questions}

1. What do you think about the sources of knowledge acquisition?

2. What do you think about your role in building the learners' knowledge?

3. What do you think about the learners' status in your teaching?

4. To what extent do you take care of your learners' needs in your teaching career? How?

5. Do you ever see any connection between your current style of teaching and your beliefs about knowledge acquisition? if yes, how is your teaching style informed by your knowledge acquisition beliefs?

Acknowledgements

Not applicable.

\section{Author's contributions}

The author(s) read and approved the final manuscript.

\section{Funding}

No funding sponsored this study.

\section{Availability of data and materials}

Data sharing is not applicable to this study because confidentiality of the data was assured when collecting the data.

\section{Competing interests}

The authors declare that they have no competing interests.

Received: 6 August 2019 Accepted: 20 July 2020

Published online: 10 August 2020

\section{References}

Abd Alsmaie, M., \& Ammar, I. (2011). An investigation of the relationships between EFL pre-service teachers' epistemological beliefs and their learning strategies, teaching practices and foreign language classroom anxiety. Language and Education, $30(3), 12-45$

Aragão, R. C. (2011). Beliefs and emotions in foreign language learning. System, 39(3), 302-313. 
Arkoudis, S. (2003). Teaching English as a second language in science classes: Incommensurate epistemologies? Language and Education, 17, 161-173.

Ary, D., Jacobs, L., Sorensen, C., \& Razavieh, A. (2010). Introduction to research in education, (10th ed., ). Canada: Wadsworth publishing. Bandura, A. (1986). Social Foundations of Thought and Action. A Social Cognitive Theory. Prentice Hall, Englewoods Cliffs, NJ. Borg, S. (2006). Teacher cognition and language education: Research and practice. London: Continuum.

Braten, I., \& Stromso, H. I. (2005). The relationship between epistemological beliefs, implicit theories of intelligence, and selfregulated learning among Norwegian postsecondary students. British Journal of Educational Psychology, 75, 539-565.

Brooks, J. G., \& Brooks, M. G. (1999). In search of understanding: The case for the constructivist classroom. Alexandria: ASCD Publications.

Brownlee, J. (2003). Changes in primary school teachers' beliefs about knowing: A longitudinal study. Asia-Pacific Journal of Teacher Education, 37(1), 87-98.

Brownlee, J., Purdie, N., \& Boulton-Lewis, G. (2001). Changing epistemological beliefs in pre-service teacher education students. Teaching in Higher Education, 6(2), 247-268.

Buehl, M. M. (2003). At the crossroads: Exploring the intersection of epistemological beliefs, motivation, and culture. Chicago: The annual conference of American Educational Research Association.

Buehl, M. M., \& Alexander, P. A. (2005). Beliefs about academic knowledge. Educational Psychology Review, 13, 385-418.

Chai, C. S., Teo, T., \& Lee, C. B. (2009). The change in epistemological beliefs and beliefs about teaching and learning: A study among pre-service teachers. Asia-Pacific Journal of Teacher Education, 37, 351-362. https://doi.org/10.1080/13598660903250381.

Chan, K. (2003). Hong Kong teacher education students' epistemological beliefs and approaches to learning. Research in Education, 69, 36-50.

Chan, K. W., \& Elliott, R. G. (2002). Exploratory study of Hong Kong teacher education students' epistemological beliefs: Cultural perspectives and implications on beliefs research. Contemporary Educational Psychology, 27, 392-414.

Chan, K. W., \& Elliott, R. G. (2004). Relational analysis of personal epistemology and conceptions about teaching and learning. Teaching and Teacher Education, 20,817-831.

Charmaz, K. (2006). Constructing grounded theory. London: Sage.

Cheng, M. H. M., Chan, K. W., Tang, Y. F. S., \& Cheng, Y. N. A. (2009). Pre-service teacher education students' beliefs about knowing and their conceptions of teaching. Teaching and Teacher Education, 25, 319-327.

Clarebout, G., Elen, J., Luyten, L., \& Bamps, H. (2001). Assessing epistemological beliefs: Schommer's questionnaire revisited. Educational Research and Education, 7, 53-77.

Cotterall, S. (1999). Key variables in language learning: What do learners believe about them? System, 27, 493-513.

Dincol, S., Temelb, S., Oskayc, O., Erdoand, U., YÕlmaze, A., et al. (2011). The effect of matching learning styles with teaching styles on success. Procedia, 15, 854-858.

Donmoyer, R. (2001). Paradigm talk reconsidered. In V. Richardson (Ed.), Handbook of research on teaching, (4th ed., pp. 174197). Washington, D.C.: American Education Research Association.

Duell, O., \& Schommer-Aikins, M. (2001). Measures of people's beliefs about knowledge and learning. Educational Psychology Review, 13(4), 4-19.

Eren, A. (2010). Consonance and dissonance between Turkish prospective teachers' values and practices: Conceptions about teaching, learning, and assessment. Australian Journal of Teacher Education, 35(3), 27-48.

Flores, B. B. (1999). Bilingual teachers' epistemological beliefs about the mature of bilingual children's cognition and their relation to perceived teaching practices. Unpublished Dissertation, University of Texas at Austin.

Gholami, K., \& Husu, J. (2010). How do teachers reason about their practice? Representing the epistemic nature of teachers' practical knowledge. Teaching and Teacher Education, 26(8), 20-29.

Grasha, A. (2002). Teaching with style, (2nd ed., ). San Bernadino: Alliance Publisher.

Haberman, M. (1995). Star teachers of children in poverty. West Lafayette: Kappa Delta Pi.

Haberman, M. (1996). Selecting and preparing culturally competent teachers for urban schools. In J. Sikula, T. J

Hashweh, M. Z. (1996). Effects of science teachers' epistemological beliefs in teaching. Journal of Research in Science Teaching, 33(1), 47-63.

Heimlich, E., \& Norland, E. (1994). Developing teaching style in adult education. San Francisco: Jossey-Bass.

Henson, K. T., \& Borthwick, P. (1984). Matching styles: A historical look. Theory Into Practice, 23, 3-9.

Hofer, B. K. (2000). Dimensionality and disciplinary differences in personal investigating change in epistemic beliefs: An evaluation of the impact of student teachers' beliefs on instructional preference and teaching competence.

Hofer, B. K. (2001). Personal epistemology research: Implications for learning and instruction. Educational Psychology Review, 13(4), 353-382.

Hofer, B. K. (2004). Exploring the dimensions of personal epistemology in differing classroom contexts: Student interpretations during the first year of college. Contemporary Educational Psychology, 29, 129-163.

Hofer, B. K., \& Pintrich, P. R. (1997). The development of epistemological theories: Beliefs about knowledge, knowing, and their relation to learning. Review of Educational Research, 67(1), 88-140.

Hofer, B. K., \& Pintrich, P. R. (2002). Personal epistemology. The psychology of beliefs about knowledge and knowing. Mahwah: Erlbaum.

Horwitz, E. K. (1999). Cultural and situational influences on foreign language learners' beliefs about language learning: A review of BALLI studies. System, 27, 557-576.

Iranmehr, A., \& Davari, H. (2017). English language education in Iran: A site of struggle between globalized and localized versions of English. Iranian Journal of Comparative Education, 1(2), 70-84.

Janfeshan, K. (2017). Iranian EFL teachers' beliefs about how to teach English grammar. Porto Alegre, 8(2), 335-354.

Jarvis, P. (2004). Adult education and lifelong learning: Theory and practice. London: Routledge Falmer.

Kaartinen-Koutaniemi, M., \& Lindblom-Ylänne, S. (2008). Personal epistemology of psychology, theology and pharmacy students: A comparative study. Studies in Higher Education, 33, 179-191. https://doi.org/10.1080/03075070801916088.

Kagan, D. M. (1992). Implication of research on teacher belief. Educational Psychologist, 27, 65-90. https://doi.org/10.1207/ s15326985ep2701_6.

Ketabi, S., Zabihi, R., \& Ghadiri, M. (2012). Critical thinking across the ELT curriculum: A mixed methods approach to analyzing L2 teachers' attitudes towards critical thinking instruction. International Journal of Research Studies in Education, 3, 15-30. 
Kienhues, D., Bromme, R., \& Stahl, E. (2008). Changing epistemological beliefs: The unexpected impact of a short-term intervention. British Journal of Educational Psychology, 78, 545-565.

Korthagen, F. A. J. (2004). In search of the essence of a good teacher: Towards a more holistic approach in teacher education. Teaching and Teacher Education, 20, 77-97. https://doi.org/10.1016/j.tate.2003.10.002.

Kuhn, D., \& Weinstock, M. (2002). What is epistemological thinking and why does it matter? In B. Hofer, \& P. Pintrich (Eds.), Personal epistemology: The psychology of beliefs about knowledge and knowing, (pp. 121-144). Mahwah: Lawrence Erlbaum.

Kumaravadivelu, B. (1994). The post method condition: (E) merging strategies for second/foreign language teaching. TESOL Quarterly, 28, 27-48.

LaBillois, J. M., \& Lagacé-Séguin, D. G. (2007). Does a good fit matter? Exploring teaching styles, emotion regulation, and child anxiety in the classroom. Early Child Development and Care 3, 1-14.

Lee, S., \& Schallert, D. L. (2016). Becoming a teacher: Coordinating past, present, and future selves with perspectival understandings about teaching. Teaching and Teacher Education, 56, 72-83.

Lim, C. P., \& Chai, C. S. (2008). Teachers' pedagogical beliefs and their planning and conduct of computer-mediated classroom lessons. British Journal of Educational Technology, 39, 807-828.

Mardali, J., Siyyari, M., \& Lu, X. (2019). English teachers' beliefs and practices in teaching vocabulary: The case of teaching experiences. Cogent Education, 6(1), 1-33. https://doi.org/10.1080/2331186X.2019.1686812.

Mason, L., \& Bromme, R. (2010). Situating and relating epistemological beliefs into metacognition: Studies on beliefs about knowledge and knowing. Metacognition Learning, 5, 1-6. https://doi.org/10.1007/s11409-009-9050-8.

McCrum, E. (2013). History teachers' thinking about the nature of their subject. Teaching and Teacher Education, 35, 73-80.

Moodie, I. (2016). The anti-apprenticeship of observation: How negative prior language learning experience influences English language teachers' beliefs and practices. System, 60, 29-41.

Muis, K., Bendixen, L. D., \& Haerle, F. C. (2006). Domain-generality and domain specificity in personal epistemology research: Philosophical and empirical reflections in the development of a theoretical framework. Educational Psychology Review, 18, 3-54. https://doi.org/10.1007/s10648-006-9003-6.

Nespor, J. (1987). The role of beliefs in the practice of teaching. Journal of Curriculum Studies, 19, 317-328. https://doi.org/10. 1080/0022027870190403.

Ng, W., Nicholas, H., \& Williams, A. (2010). School experience influences on pre-service teachers' evolving beliefs about effective teaching. Teaching and Teacher Education, 26, 278-289.

Olafson, L., \& Schraw, G. (2006). Teachers' beliefs and practices within and across domains. International Journal of Educational Research, 45, 71-84.

Pajares, M. F. (1992). Teacher's beliefs and educational research: Cleaning up a messy construct. Review of Educational Research, 62(3), 307-332.

Patton, M. Q. (1990). Qualitative evaluation and research methods, (2nd ed., ). Newbury Park: Sage Publications.

Perry, W. G. (1970). Forms of intellectual and ethical development in the college years. New York: Academic Press.

Perry, W. G. (1981). Cognitive and ethical growth: The making of meaning. In A. W. Chickering (Ed.), The modern American college, (pp. 76-116). San Francisco: Jossey- Bass.

Ravindran, B., Greene, B. A., \& DeBacker, T. K. (2005). Predicting pre-service teachers' cognitive engagement with goals and epistemological beliefs. The Journal of Educational Research, 98, 222-232.

Riazi, A. M., \& Candlin, C. N. (2014). Mixed-methods research in language teaching and learning: Opportunities, issues and challenges. Language Teaching, 47, 135-173.

Richardson, V. (1996). The role of attitudes and beliefs in learning to teach. In J. Sikula, T. J. Buttery, \& E. Guyton (Eds.), Handbook of research on teacher education, (2nd ed., pp. 102-119). Macmillan: New York.

Roth, G., \& Weinstock, M. (2013). Teachers' epistemological beliefs as an antecedent of autonomy-supportive teaching. Motivation and Emotion, 37, 402-412.

Schommer, M. A. (1990). Effects of beliefs about the nature of knowledge on comprehension. Journal of Educational Psychology, 82, 498-504.

Schommer, M. A., Crouse, A., \& Rhodes, N. (1992). Epistemological beliefs and mathematical text comprehension: Believing it is simple does not make it so. Journal of Educational Psychology, 84(4), 435-443.

Schommer-Aikins, M. (2004). Explaining the epistemological belief system: Introducing the embedded systemic model and coordinated research approach. Educational Psychologist, 39(1), 19-29.

Schommer-Aikins, M., Duell, O. K., \& Hutter, R. (2005). Epistemological beliefs, mathematical problem-solving beliefs, and academic performance of middle school students. The Elementary School Journal, 105(3), 289-304.

Schommer-Aikins, M., Duell, P. K., \& Barker, S. (2003). Epistemological beliefs across domains using biglan's classification of academic disciplines. Research in Higher Education, 44(3), 347-366.

Schraw, G., \& Olafson, L. (2003). Teachers' epistemological world views and educational practices. Issues in Education, 8, 99148.

Sinatra, G. M., \& Kardash, C. M. (2004). Teacher candidates' epistemological beliefs, dispositions, and views on teaching as persuasion. Contemporary Educational Psychology, 29, 483-498.

Sosu, E., \& Gray, D. (2012). Investigating change in epistemic beliefs: An evaluation of the impact of student teachers' beliefs on instructional preference and teaching competence. International Journal of Educational Research, 53, 80-92.

Springer, L., Stanne, M. E., \& Donovan, S. S. (1999). Effects of small-group learning on undergraduates in science, mathematics, engineering, and technology: A meta-analysis. Review of Educational Research, 69, 21-51.

Strauss, A., \& Corbin, J. (1998). Basics of qualitative research: Techniques and procedures for developing grounded theory, (2nd ed. , ). Thousand Oaks, London, New Delhi: Sage Publications.

Tang, J. (2007). Review of researches on students' epistemological beliefs. Journal of Mathematics Education (Chinese Version), 1, 29-33.

Stensrud, R., \& Stensrud, K. (1983) 'Coping skills training: A systematic approach to stress management counseling'. The Personnel and Guidance Journal, 62(4), p. 214-218.

Tsai, C. (2002). Nested epistemologies: science teachers' beliefs of teaching, learning and science. International Journal of Science Education, 28, 771-783. https://www.tandfonline.com/doi/abs/10.1080/09500690701191425

Tsai, C., \& Kuo, P. (2008). Cram school students' conceptions of learning and learning science in Taiwan. International Journal of Science Education, 30, 353-375. https://doi.org/10.1080/09500690701191425. 
Windschitl, M. (2002). Framing constructivism in practice as the negotiation of dilemmas: An analysis of the conceptual, pedagogical, cultural, and political challenges facing teachers. Review of Educational Research, 72, 131-175.

Wong, B., \& Chai, C. S. (2010). Asian personal epistemologies and beyond: Overview and some reflections. The Asia-Pacific Education Researcher, 19(1), 1-6.

Yadav, A., \& Koehler, M. (2007). The role of epistemological beliefs in Preservice teachers' interpretation of video cases of early-grade literacy instruction. Journal of Technology and Teacher Education, 15(3), 335-361.

\section{Publisher's Note}

Springer Nature remains neutral with regard to jurisdictional claims in published maps and institutional affiliations.

Submit your manuscript to a SpringerOpen ${ }^{\odot}$ journal and benefit from:

- Convenient online submission

- Rigorous peer review

- Open access: articles freely available online

- High visibility within the field

- Retaining the copyright to your article

Submit your next manuscript at $\boldsymbol{\nabla}$ springeropen.com 